\title{
Penerapan Model Pembelajaran Means-Ends analysis untuk MeningKatKan Kemampuan Pemecahan MaSalah Matematis SisWa
}

\author{
Nindy Citroresmi $\mathrm{P}^{1)}$, Nurhayati ${ }^{2)}$ \\ 1)Program Studi Pendidikan Matematika, STKIP Singkawang, Indonesia \\ E-mail:nindy.citroresmi@gmail.com \\ 2)Program Studi Pendidikan Matematika, STKIP Singkawang, Indonesia \\ E-mail: nurhayati@stkipsingkawang.ac.id
}

\begin{abstract}
Abstrak. Penelitian ini bertujuan untuk mengetahui penerapan model pembelajaran Means Ends Analysis (MEA) dalam meningkatkan kemapuan pemecahan masalah matematis siswa. Metode yang digunakan dalam penelitian ini adalah metode kuantitatif dengan bentuk penelitian yang digunakan adalah eksperimen semu dengan one group pretest posttest design. Populasi dalam penelitian ini adalah sema siswa kelas VIII SMP N 11 Singkawang. Sampel dipilih dengan menggunakan teknik purposive sampling. Hasil analisis data menunjukkan bahwa ; (1) terdapat peningkatan kemampuan pemecahan masalah matematis siswa berdasarkan uji gain dan uji t, dengan perhitungan uji gain yang berada dalam kategori sedang dan perrhitungan uji $\mathrm{t}$ dimana nilai $\mathrm{t}$ hitung $>\mathrm{t}$ tabel; (2) Respon siswa terhadap model pembelajaran means ends analysis dikategorikan baik; (3) aktivitas belajar siswa dalam mengikuti pembelajaran, siswa terlihat aktif mempelajari materi Sistem Persamaan Linear Dua Variabel (SPLDV). Dengan demikian dapat disimpulkan bahwa model pembelajaran means ends analysis dapat meningkatkan kemampuan pemecahan masalah matematis siswa
\end{abstract}

Kata Kunci: Means Ends Analysis, Pemecahan Masalah Matematis

\section{PENDAHULUAN}

Dalam pembelajaran Matematika, idealnya siswa dibiasakan untuk memperoleh pemahaman melalui pengalaman dan pengetahuannya yang dikembangkan oleh siswa sesuai dengan perkembangan berpikirnya. Hal ini sejalan dengan maksud pembelajran yang dirumuskan oleh National Council of Teachers of Mathematics (2000) bahwa siswa harus mempelajari matematika melalui pemahaman dan aktif membangun pengetahuan baru dari pengalaman dan pengetahuan yang telah dimiliki sebelumnya. Nuansa pembelajaran yang berpusat pada siswa, di mana siswa diberikan kesempatan untuk mengkonstruksikan pengetahuan dan keleluasaan dalam memecahkan suatu permasalahan diduga akan mendukung peningkatan kemampuan pemecahan masalah matematika siswa.
Namun pada kenyataannya, dalam pelaksanaan matematika di dalam kelas umumnya hanya terfokus kepada ketercapaian target materi menurut buku ajar ataupun kurikulum, bukan pada materi yang siswa pelajari.Hal ini menyebabkan siswa hanya menghafal konsep dan tidak memahami maksud dari isinya. Pembelajaran matematika pada umumnya juga kurang memperhatikan pengembangan kemampuan berpikir tingkat tinggi seperti kemampuan pemecahan masalah. Padahal kemampuan ini sangat penting, sebab di dalam kehidupan seharihari setiap orang selalu dihadapkan pada berbagai masalah yang harus dipecahkan.

Kemampuan pemecahan masalah merupakan satu diantara bagian yang penting di dalam kurikulum matematika, karena di dalam proses pembelajaran maupun penyelesaian siswa memungkinkan untuk dapat memperoleh 
pengetahuan serta menggunakan pengetahuan yang sudah dimiliki untuk digunakan dalam pemecahan masalah. Kemampuan penyelesaian (pemecahan) masalah menjadi tujuan utama diantara beberapa tujuan belajar matematika. Menurut Cooney dalam Sumarmo (2014) orang yang memiliki kemampuan pemecahan masalah mampu berpikir analitik dalam mengambil keputusan dalam kehidupan sehari-hari dan membantu meningkatkan kemampuan berpikir kritis dalam menghadapi situasi baru.

Namun pada kenyataannya, yang terjadi di sekolah kemampuan pemecahan masalah sama sekali tidak diperhatikan dan masih tergolong rendah. Hal ini dapat dilihat dari hasil pengerjaan soal yang diberikan kepada siswa terutama soal yang berbentuk soal cerita.kebanyakan siswa belum bisa menyelesaikan permasalahan, mulai dari memahami masalah, merencanakan penyelesaian dan lainnya. Untuk itu dalam pembelajaran matematika perlu dipertimbangkan tugas matematika dan suasana belajar yang mendukung untuk mendorong munculnya kemampuan tersebut.Pertimbangan ini menyangkut keputusan pembelajaran yang digunakan di kelas yang perlu ditempuh oleh guru.

Satu di antara keputusan yang perlu diambil oleh guru menyangkut tentang pembelajaran adalah pemilihan model pembelajaran yang akan digunakan. Dalam hal ini kita menyadari bahwa masih banyak guru matematika yang beranggapan bahwa siswa merupakan objek dari belajar. . Hal ini sejalan dengan Hadi (2005) yang menyebutkan bahwa ciri praktek pendidikan di Indonesia selama ini adalah pembelajaran yang berpusat pada guru. Akibatnya siswa sulit memahami materi yang disampaikan dan sering terkesan membosankan. Gejala tidak efisien, tidak efektif dan kurang relevan tersebut tampak dari beberapa indikator seperti, kurangnya motivasi belajar siswa, penyelesaian tugas siswa tidak sesuai waktu yang ditentukan dan hasil tes yang menunjukkan nilai yang rendah. Dengan kondisi pembelajaran tersebut maka sulit untuk mencapai tujuan pembelajaran yang optimal.

Oleh karena itu perlu diterapkan suatu model pembelajaran yang mampu memfasilitasi kemampuan pemecahan masalah siswa dan menjadikan siswa lebih aktif dalam pembelajaran. Satu diantara model pembelajaran yang dianggap tepat untuk memfasilitasi kemampuan pemecahan masalah siswa adalah model pembelajran means ends analysis.

Model Pembelajaran Means Ends Analysis (MEA) adalah model pembelajaran variasi antara metode pemecahan masalah dengan sintaks yang menyajikan materinya pada pendekatan pemecahan masalah berbasis heuristic yaitu berupa rangkaian pertanyaan yang merupakan petunjuk untuk membantu siswa dalam memecahkan masalah yang dihadapi, Simon (Huda, 2014).

Satu di antara materi dalam matematika yang secara simultan terbangun terutama sejak awal pembelajaran matematika di sekolah menengah pertama adalah persamaan linear dua variabel (SPLDV). Persamaan linear dua variabel merupakan bagian dari aljabar. Manusia sering mengalami suatu kegiatan aljabar diantaranya persamaan linear dua variabel dalam kehidupan sehari-hari. Misalnya dalam permasalahan yang berhubungan dengan jual beli, menaksir harga barangdan sebagainya.

Agar terbangunnya kebermaknaan dalam materi persamaan linear dua variabel maka aspek pemecahan masalah terutama dari konteks yang ada di sekitar siswa perlu dijadikan sebagai acuan. Dengan demikian, untuk mengkonstruksi pemahaman matematis yang kokoh, diperlukan model pembelajaran yang memuat soal-soal tidak rutin, menantang, berangkat dari masalah seharihari yang memerlukan analisis, tidak hanya bisa diselesaikan dengan langkah-langkah baku yang prosedural dan mekanistis.

Berdasarkan keterangan dan penjelasan sebelumnya, peneliti termotivasi untuk model pembelajaran yang dapat meminimalkan suasana kurang kondusif dalam pembelajaran. Model pembelajaran yang dapat melibatkan semua siswa secara aktif mengikuti kegiatan pembelajaran pemecahan masalah matematis. Model pembelajaran tersebut memberikan penjelasan tahap pemecahan masalah yang akan dilakukan selama pembelajaran. Penerapan model pembelajaran mans end analysis merupakan salah satu langkah untuk meningkatkan kemampuan 
pemecahan masalah siswa yang sangat penting untuk pemahaman ilmu matematika dan ilmu lain yang dipelajari siswa pada tahap lanjut. Oleh karena itu peneliti bertujuan untuk menerapkan model pembelajaran means ends analysis untuk meningkatkan kemampuan pemecahan masalah matematis siswa pada materi SPLDV.

\section{Metode Penelitian}

Metode penelitian yang digunakan dalam penelitian ini adalah eksperimen adalah metode metode eksperimen dengan bentuk penelitian eksperimen semu serta rancangan penelitian yang digunakan adalah one group pretest posttest design. Rancangan ini terdapat pretes sebelum diberi perlakuan.Dengan demikian dapat diketahui lebih akurat, karena dapat membandingkan dengan keadaan sebelum diberiperlakuan.

\begin{tabular}{ccc}
\hline Pretest & Perlakuan & Posttest \\
\hline $\mathrm{T}_{1}$ & $\mathrm{X}$ & $\mathrm{T}_{2}$ \\
\hline
\end{tabular}

Keterangan :

$\mathrm{T}_{1}$ : Tes awal (pretest)

$\mathrm{T}_{2}$ : Tes akhir (posttest)

$\mathrm{X}$ : Penerapan model pembelajaran dengan

\section{Model Pembalajaran Means Ends Analiysis (MEA)}

Adapun yang menjadi subjek dalam penelitian ini adalah siswa kelas VIII SMP $\mathrm{N} 11$ Singkawang.Instrument yang digunakan dalam penelitian ini adalah berupa,(1)soal-soal uraian yang diberikan dalam bentuk pretest dan posttest yang merupakan tes kemampuan pemecahan masalah yang sesuai dengan indikator-indikator untuk mengukur tingkat kemampuan pemecahan masalah, (2)Angket respon siswa, angket ini digunakan untuk mengukur sikap dan tanggapan siswa terhadap model pembelajaran Means Ends Analiysis. Angket yang digunakan adalah angket jenis tertutup, dimana siswa telah diberikan jawaban tiap angket.Pertanyaan yang diberikan diupayakan untuk mengungkap minat dan kesan siswa terhadap komponen-komponen dalam kegiatan Model Pembelajaran Means Ends Analiysis (MEA) yang diberikan sesudah mereka mendapatkan perlakuan. (3) lembar pengamatan, lembar ini digunakan untuk mengamat iaktivitas
siswa.Dalam lembar pengamatan disediakan beberapa indikator dari aktivitas yang diharapkan nampak pada siswa.Pengamat menuliskan angka pada table kategori pengamatan.

Data yang akan dianalisis dalam penelitian ini, diperoleh dari tes kemampuan pemecahan masalah matematis, tes dilakukan pada awal pembelajaran (sebelum perlakuan), yang disebut sebagai pretest dan pada akhir pembelajaran (setelah perlakuan), yang disebut postes. Dari skor pretes dan postes tersebut, dihitung rata-rata hasil pretes dan postestnya kemudian dilanjutkan dengan menentukan perhitungan Gain, perhitungan normalitas selanjutnya pengujian hipotesis.

Selain data tes, data hasil observasi dan data respon siswa juga dianalisis.Untuk data hasil observasi akan dianalasis dengan menghitung persentase tingkah laku siswa pasif dan aktif pada masing-masing kategori pada item pernyataan, setelah dicari persentase masing-masing tingkah laku baik aktif maupun pasif, selanjutnya adalah melakukan perbandingan persentase tingkah laku aktif dan pasif agar didapatkan kesimpulan tentang aktivitas siswa dalam pembelajaran dengan menggunakan model pembelajaran Means Ends Analiysis.

Data respon siswa dianalisis dengan menghitung persentase siswa yang memilih suatu kategori atau kriteria dengan jalan banyaknya siswa yang memilih suatu kategori atau kriteria dibagi dengan jumlah butir tanggapan dikali dengan jumlah banyaknya siswa.Setelah dilakukan perhitungan barulah kemudian disimpulkan berdasarkan interpretasi respon.

\section{HASIL DAN PEMBAHASAN}

Berdasarkan hasil penelitian yang diperoleh dari tes kemampuan pemecahan masalah matematis, lembar observasi, dan angket yang digunakan untuk menjawab sub masalah yang berupa peningkatan kemampuan pemecahan masalah matematis siswa, aktivitas siswa dan respon siswa terhadap model pembelajaran Means Ends Analiysis. Berikut adalah analisis yang meliputi kemampuan pemecahan masalah matematis 


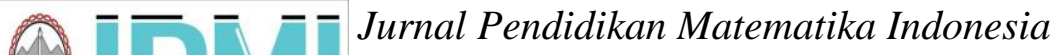

Dari hasil tes untuk kemampuan pemecahan masalah matematis siswa dari pretes dan postes dapat dilihat dari tabel berikut.

TABEL I

REKAPITULASI INDIKATOR KEMAMPUAN PEMECAHAN MASALAH MATEMATIS

\begin{tabular}{cccc}
\hline $\begin{array}{c}\text { Kemampuan } \\
\begin{array}{c}\text { Penyelesaian Masalah } \\
\text { Matematis }\end{array}\end{array}$ & $\begin{array}{c}\text { Prete } \\
\text { st }\end{array}$ & $\begin{array}{c}\text { Postt } \\
\text { est }\end{array}$ & $\begin{array}{c}\text { Penin } \\
\text { gkata } \\
\text { n }\end{array}$ \\
\hline Memahami masalah & $41 \%$ & $81 \%$ & $40 \%$ \\
Menyusun Rencana & $34 \%$ & $75 \%$ & $41 \%$ \\
Melaksanakan Rencana & $45 \%$ & $83 \%$ & $38 \%$ \\
Memeriksa Kembali & $22 \%$ & $71 \%$ & $49 \%$ \\
Rata-rata & $\mathbf{3 6 \%}$ & $\mathbf{7 8 \%}$ & $\mathbf{4 2 \%}$ \\
\hline
\end{tabular}

Berdasarkan Tabel 1 dapat dijelaskan bahwa untuk masing-masing indicator pada kemampuan pemecahan masalah matematis mengalami peningkatan rata-rata sebesar $42 \%$.

Selanjutnya dari hasil yang diperoleh melalui pretest dan posttes selanjutnya dihitung nilai ratarata pretest, posttest serta perhitungan gain yang disajika kedalam Tabel II berikut ini.

TABEL II

NILAI RATA-RATA KELAS EKSPERIMEN

\begin{tabular}{cccc}
\hline \multirow{2}{*}{ Kelas } & \multicolumn{3}{c}{ Nilai Rata-rata } \\
\cline { 2 - 4 } & Pretest & Posttest & Gain \\
\hline Eksperimen & 11,84 & 15,8 & 0,5 \\
\hline
\end{tabular}

Dari tabel di atas, terlihat bahwa gain berada pada angka 0,5 yang berarti dapat disimpulkan bahwa gain termasuk kedalam kategori sedang karena $0,3 \leq \mathrm{g}<0,7$. Untuk mengetahui apakah data yang diperoleh berasal dari subjek yang berdistribusi normal atau tidak selanjutnya dilakukan uji normalitas dengan menggunakan uji lilifors. Hasil uji normalitas dapat dilihat pada tabel berikut ini:

TABEL III

UJI NORMALITAS DATA

\begin{tabular}{cccccc}
\hline Kelompok & $\begin{array}{c}\text { Sampe } \\
\mathbf{l}\end{array}$ & $\begin{array}{c}\text { Rata } \\
\text {-rata }\end{array}$ & Sd & Lhitung & Ltabel \\
\hline $\begin{array}{c}\text { Eksperime } \\
\mathrm{n}\end{array}$ & 25 & 79 & 13, & 0,065 & 0,17 \\
& & & 5 & 9 & 3 \\
\hline
\end{tabular}

Pengujian dilakukan pada taraf signifikan 0,05 untuk $\mathrm{n}=25$. Dari tabel III di atas, dapat disimpulkan bahwa data berdistribusi normal karena $\mathrm{L}_{\text {hitung }}<\mathrm{L}$ tabel yaitu $0,0659<0,173$.

Dari hasil perhitungan didapat bahwa t hitung $>$ $t$ tabel yaitu 2,230 > 1,711. Dengan demikian Ho ditolak dan Ha diterima pada taraf signifikan $\alpha=$ 0,05 sehingga dapat disimpulkan bahwa terdapat peningkatan kemampuan pemecahan masalah matematis siswa dengan menggunakan model pembelajaran Means Ends Analysis (MEA).

Setelah proses belajar dengan model Means Ends Analysis (MEA selesai, selanjutnya kepada siswa diberikan angket respon untuk mengetahui tanggapan siswa selama proses pembelajaran berlangsung. Angket respon berupa angket tertutup, siswa hanya memilih salah satu tanggapan yang telah disediakan. Berikut adalah hasil angket respon siswa terhadap model pembelajaran Means Ends Analysis (MEA).

TABEL IV

REKAPITULASI RESPON SISWA

\begin{tabular}{ccccccc}
\hline Nomor & \multicolumn{4}{c}{ Kategori Pernyataan } & Jumlah \\
\cline { 2 - 6 } Pernyataan & SS & S & R & TS & STS & Skor \\
\hline 1 & 13 & 10 & 2 & 0 & 0 & 111 \\
2 & 3 & 2 & 4 & 7 & 9 & 92 \\
3 & 8 & 17 & 0 & 0 & 0 & 108 \\
4 & 0 & 0 & 5 & 10 & 10 & 105 \\
5 & 13 & 12 & 0 & 0 & 0 & 113 \\
6 & 2 & 1 & 1 & 9 & 12 & 103 \\
7 & 10 & 13 & 2 & 0 & 0 & 108 \\
8 & 1 & 1 & 3 & 9 & 11 & 103 \\
Skor Total & 50 & 56 & 17 & 35 & 42 & 843 \\
\hline
\end{tabular}

Dari tabel di atas kemudian dihitung tingkat persetujuan terhadap pembelajaran Means Ends Analysis, didapatlah persentase sebesar 84,3\% untuk persetujuan terhadap model pembelajaran Means Ends Analysis.

Aktivitas belajar siswa dengan menggunakan model pembelajaran Means Ends Analysis (MEA) diperoleh dengan menggunakan lembar pengamatan aktivitas siswa,berikut adalah hasil observasi aktivitas siswa selama proses pembelajaran dengan menggunakan model pembelajaran Means Ends Analysis (MEA).dari hasil pengamatan aktivitas belajar siswa dalam mengikuti pembelajaran, siswa terlihat aktif mempelajari materi pecahan. Selain itu perilaku ditunjukan siswa melalui aktivitas bertanya yang 
baik kepada guru maupun teman yang lain,siswa juga terlihat serius dalam mengikuti setiap peragaan yang disajikan oleh guru. Dengan demikian siswa baik pada pembelajaran pecahan dengan menggunakan model pembelajaran Means Ends Analysis (MEA).

\section{Pertemuan pertama}

1. Persentase tingkah laku siswa pasif pada kategori 1,2, 3 adalah sebagai berikut:

$=2,78 \%+22,9 \%+6,96 \%$

$=32,64 \%$

2. Persentase tingkah laku siswa aktif pada kategori 4, 5, 6, 7 adalah sebagai berikut : $=17,42 \%+15,33 \%+14,63 \%+20,55 \%$ $=67,93 \%$

\section{Pertemuan kedua}

1. Persentase tingkah laku siswa pasif pada kategori 1, 2, 3 adalah sebagai berikut: $=1,87 \%+21,56 \%+7,81 \%$ $=31,24 \%$

2. Persentase tingkah laku siswa aktif pada kategori 4, 5, 6, 7 adalah sebagai berikut: $=20 \%+16,87 \%+14,68 \%+19,68 \%$ $=71,23 \%$

Skor rata-rata siswa pasif

$$
\begin{aligned}
= & \frac{p \cdot \text { pertama }+ \text { p.kedua }}{2} \\
= & \frac{32,64+31,24}{2} \\
= & 31,94 \%
\end{aligned}
$$

Skor rata-rata siswa aktif

$=\frac{p \cdot \text { pertama }+ \text { p.kedua }}{2}$

$=\frac{67,93+71,23}{2}$

$=69,58 \%$

Rata-rata tingkah laku siswa aktif sebesar $69,58 \%$ lebih besar dari rata-rata tingkah laku siswa pasif yaitu sebesar $31,94 \%$. Dengan demikian siswa aktif pada pembelajaran dengan menggunakan model pembelajaran Means Ends Analysis.
Dari ketiga uraian pembahasan yang telah diungkapkan diatas maka terlihatlah bahwa pembelajaran dengan menggunakan model pembelajaran Means Ends Analysis (MEA) pada materi SPLDV dinyatakan dapat meningatkan kemaampuan pemecahan masalah, dapat membuat siswa lebih aktif dalam kegiatan pembelajaran dan siswa merespon dengan baik kegiatan pembelajaran

\section{KESIMPULAN DAN SARAN}

Berdasarkan hasil pengolahan data penelitian yang dilakukan, secara umum dapat disimpulkan bahwa pembelajaran dengan model pembelajaran Means Ends Analysis (MEA) bagi siswa kelas VIII SMP Negeri 11 Singkawang dikatakan tepat untuk meningkatkan kemampuan pemecahan masalah matematis siswa. Hal tersebut karena berdasarkan peningkatan kemampuan pemecahan masalah matematis siswa dengan menggunakan model pembelajaran Means Ends Analysis (MEA) Aktivitas siswa dengan menggunakan model pembelajaran Means Ends Analysis (MEA) dikatakan baik, karena rata-rata siswa aktif lebih besar dibandingkan dengan rata-rata siswa pasif. Respon siswa pada pembelajaran dengan menggunakan model pembelajaran Means Ends Analysis (MEA) dinyatakan sangat senang karena jumlah persentase pilihan respon posistif lebih besar dibandingkan dengan jumlah persentase respon negatif

Berdasarkan hasil penelitian yang diperoleh dalam penelitian ini, peneliti memberikan saran sebagai berikut: (1) Bagi guru yang akan melaksanakan pembelajaran dengan menggunakan model pembelajaran Means Ends Analysis (MEA) di dalam kelas sebaiknya terlebih dahulu memotivasi siswa agar mereka tidak segan untuk bertanya dan belajar dengan sungguh-sungguh. (2) Bagi guru yang ingin menerapkan pembelajaran dengan menggunakan model pembelajaran Means Ends Analysis (MEA) hendaknya melakukan penjelasan langkah-langkah pembelajaran dari model ini dengan bahasa yang sederhana yang dapat dipahami oleh siswa, sehingga model pembelajaran yang baru ini dapat diterima oleh siswa dengan benar 


\section{DAFTAR PUSTAKA}

Hadi, S. (2005). Pendidikan Matmatika Realistik dan Implementasinya. Banjarmasin: Tulip.

Huda, Miftahul. (2014). Model-model PengajarandanPembelajaran. Yogyakarta: Pustaka Pelajar
National Council of Teacher of Mathematics. (2000). Principles and Standards for School Mathematics. .

Sumarmo, Utari. (2014). Penilaian Pembelajaran Matematika.Bandung: PT Rafika Aditama. 